\title{
Application of Interval Type-2 Fuzzy Logic System in Short Term Load Forecasting on Special Days
}

\author{
Agus Dharma ${ }^{1}$, Imam Robandi ${ }^{2}$, and Mauridhi Hery Purnomo ${ }^{2}$
}

\begin{abstract}
This paper presents the application of Interval Type-2 fuzzy logic systems (Interval Type-2 FLS) in short term load forecasting (STLF) on special days, study case in Bali Indonesia. Type-2 FLS is characterized by a concept called footprint of uncertainty (FOU) that provides the extra mathematical dimension that equips Type-2 FLS with the potential to outperform their Type-1 counterparts. While a Type-2 FLS has the capability to model more complex relationships, the output of a Type-2 fuzzy inference engine needs to be type-reduced. Type reduction is used by applying the Karnik-Mendel (KM) iterative algorithm. This type reduction maps the output of Type-2 FSs into Type-1 FSs then the defuzzification with centroid method converts that Type-1 reduced FSs into a number. The proposed method was tested with the actual load data of special days using 4 days peak load before special days and at the time of special day for the year 2002-2006. There are 20 items of special days in Bali that are used to be forecasted in the year 2005 and 2006 respectively. The test results showed an accurate forecasting with the mean average percentage error of 1.0335 and $1.5683 \%$ in the year 2005 and 2006 respectively.
\end{abstract}

\section{Keywords $\longrightarrow$ STLF, interval type-2 FLS, Karnik-Mendel (KM) algorithm}

\begin{abstract}
Abstrak-Makalah ini menyajikan sebuah aplikasi Interval Type-2 Fuzzy Logic System (Interval Type-2 FLS) untuk peramalan beban jangka pendek (STLF) pada hari-hari libur dalam sebuah studi kasus di Bali, Indonesia. Sistem logika fuzzy Type-2 ditandai dengan konsep yang disebut footprint of uncertainty (FOU). Penggunaan dimensi matematika tambahan pada sistem Type-2 FLS ini memberikan hasil yang lebih baik dibandingkan dengan Type-1 FLS. Type-2 FLS juga memiliki kemampuan untuk memodelkan hubungan yang lebih kompleks dengan output dari Type-2 fuzzy inference engine yaitu memerlukan apa yang disebut dengan type reduction. Type reduction yang digunakan ini menerapkan algoritma iteratif Karnik-Mendel (KM Algorithm) yaitu pemetaan output Type-2 fuzzy set (Type-2 FSs) menjadi Type-1 fuzzy set (Type-1 FSs) dengan proses defuzzifikasi menggunakan centroid untuk selanjutnya mengkonversi Type-1 FSs ke suatu bilangan. Metode yang diusulkan ini diuji dengan data beban puncak hari libur sebenarnya pada sistem kelistrikan Bali, yaitu hari libur menggunakan beban puncak 4 hari sebelum hari libur dan pada saat hari libur untuk periode tahun 2002 hingga tahun 2006. Ada 20 item hari libur di Bali yang digunakan untuk peramalan pada tahun 2005 dan 2006. Hasil tes menunjukkan tingkat keakuratan peramalan dengan persentase kesalahan rata-rata (MAPE) sebesar 1,0335\% di tahun 2005 dan 1,5683\% di tahun 2006.
\end{abstract}

Kata Kunci-peramalan beban jangka pendek, interval type-2 FLS, algoritma iterative Karnik-Mendel

\section{INTRODUCTION}

$\mathrm{N}$ owadays electric power load forecasting techniques such as neural network and fuzzy theory are now actively being used to reduce the uncertainty and the nonlinear behavior of load. Peak load without previously estimated, will influence the operation such as scheduling and allocation of units to back up and can disrupt the electric power system's reliability. High accuracy of the load forecasting could improve the security of the power system and reduces the costs $[1,2]$.

Fuzzy set was first introduced by L.A. Zadeh in 1965 to manipulate the unprobabilistic and uncertainty of data and information. Fuzzy sets and fuzzy logic are the basis of the fuzzy system aiming to mimic how human brain works in manipulating the non-exact information.

\footnotetext{
Agus Dharma is with Department of Electrical Engineering, UniversitasUdayana, Bali, Indonesia. E-mail: agd2bali@yahoo.com.

Imam Robandi and Mauridhy Hery Purnomo are with Department of Electrical Engineering, Institut Teknologi Sepuluh Nopember, Surabaya, Indonesia.
}

Therefore, this method is suitable to model complex systems, non-linear and difficult model in uncertainty [3, 4] and these methods are implemented on short term load forecasting $[1,5,6]$.

More information on the development of Type-1 fuzzy set can be obtained in the interval Type-2 fuzzy set. Interval Type-2 fuzzy set is better used to model uncertainty and imprecision. Interval Type- 2 fuzzy sets developed by Mendel is characterized with interval Type-2 fuzzy set as the footprint of uncertainty (FOU) is limited by the superior and inferior type 1 membership function and the development of type type1 to Type-2 intervals in some cases, the results indicate better [7- 10].

A characteristic of the peak load during holidays is different from the weekdays, where load condition is not necessary and tends to decrease due to dissimilar load behavior of holidays compare with ordinary weekdays during the year [11]. There have been several research works for developing accurate load forecasting techniques for special days $[1,2,11]$.

In this paper Interval Type-2 FLS is carried out to forecast peak load on holidays in Bali electricity system 
during the year 2005 and 2006 and the results obtained are compared with the previous methods.

\section{A. Footprint of Uncertainty (FOU)}

An interval type-2 fuzzy set (Interval Type-2 FS) $\widetilde{A}$ is characterized on equation (1) [12].

$$
\begin{aligned}
& \tilde{A}=\int_{x \in X} \int_{\mu \in J_{x} \subseteq[0,1]} 1 /(x, u) \\
& =\int_{x \in X}\left[\int_{\mu \in J_{x} \subseteq[0,1]} 1 / u\right] / x
\end{aligned}
$$

where $\mathrm{x}$, the primary variable, has domain $\mathrm{X} ; \mathrm{u} \in \mathrm{U}$, the secondary variable, has domain $\mathrm{J}$, at each $\mathrm{x} \in \mathrm{X} ; \mathrm{J}_{\mathrm{x}}$ is called the primary membership of $\mathrm{x}$ and is defined in equation (5); and, the secondary grades of $A$ all equal 1 . Where that in equation (1) means: $\tilde{A}: X \rightarrow\{[a, b]: 0 \leq a$ $\leq b \leq 1\}$. Uncertainty about $\tilde{A}$ is conveyed by the union of all the primary memberships, which is called the footprint of uncertainty (FOU) of $\tilde{A}$ (see Figure 1), i.e.

$\operatorname{FOU}(\tilde{\mathrm{A}})=\underset{\forall \mathrm{x} \in \mathrm{X}}{\bigcup} \mathrm{J}_{\mathrm{x}}=\left\{(\mathrm{x}, \mathrm{u}): \mathrm{u} \in \mathrm{J}_{\mathrm{x}} \subseteq[0,1]\right\}$

The Upper Membership Function (UMF) and Lower Membership Function (LMF) of $\widetilde{A}$ are two type-1 MFs that bound the FOU (Figure 1). The UMF is associated with the upper bound of $F O U(\tilde{A})$ and is denoted $\bar{\mu}_{\tilde{A}}(x), \forall x \in X$, and the LMF is associated with the lower bound of $F O U(\tilde{A})$ and is denoted $\underline{\mu}_{\tilde{\AA}}(x), \forall x \in X$ i.e.

$$
\begin{aligned}
& \mathrm{J}_{\mathrm{x}}=\left\{(x, u) ; u \in\left\lfloor\underline{\mu}_{\tilde{\mathrm{A}}}(\mathrm{x}), \bar{\mu}_{\tilde{A}}(\mathrm{x})\right]\right\} \\
& \underline{\mu}_{\tilde{A}} \equiv \underline{F O U(\tilde{A}) \quad \forall x \in X}
\end{aligned}
$$

Where that $J_{x}$ is an interval set, i.e.

$\mathrm{J}_{\mathrm{x}}=\left\{(x, u) ; u \in\left\lfloor\underline{\mu}_{\tilde{\mathrm{A}}}(\mathrm{x}), \bar{\mu}_{\tilde{A}}(\mathrm{x})\right]\right\}$

so that $\operatorname{FOU}(\tilde{A})$ in Equation(2) can also be expressed as

$$
\operatorname{FOU}(\tilde{A}) \equiv \bigcup_{\forall x \in X}\left[\mu_{\tilde{A}}(\mathrm{x}), \bar{\mu}_{\tilde{A}}(\mathrm{x})\right]
$$

For continuous universes of discourse $X$ and $U$, and embedded Interval Type-2 FS $\tilde{A}$ is

$\tilde{A}_{e} \equiv \int_{x \in X}[1 / u] / x \quad u \in J$

Note that equation (7) means: $\tilde{A}_{e}: X \rightarrow\{u: 0 \leq u \leq 1\}$ The set $\tilde{A}_{e}$ is embedded in $\tilde{A}$ such that at each $x$ it only has one secondary variable (i.e., one primary membership whose secondary grade equals 1). Examples of $\tilde{A}_{e}$ are ${ }^{1 / \bar{\mu}_{\tilde{A}}}{ }^{(x)}$ and, ${ }^{1 /} \underline{\mu}_{\tilde{A}}{ }^{(x)} \forall x \in X$.

\section{B. Structure of Interval Type-2 FLS}

An Interval Type- 2 FLS contains five components that are interconnected. The five components are fuzzifier, rules, inference engine, type-reducer and defuzzifier has shown in Figure 2. Mapping process from crisp input to crisp output can be expressed quantitatively as $Y=f(x)$.

In Figure 2. shows that the crisp inputs are fuzzified into either type-0 (known as singleton fuzzification), type-1 or Interval Type-2 FSs, which then the inference engine and the rule base to produce output Interval Type2 FSs. These Interval Type- 2 FSs are then processed by a type-reducer (which combines the output sets and then performs a centroid calculation), leading to an interval Type-1 FSs called the type-reduced sets. A defuzzifier then defuzzifies the type-reduced sets to produce crisp outputs [12].

\section{Membership Functions and Fuzzy Rules}

The advantages of fuzzy inference is easily formulate the experience and knowledge of experts and very flexible in forecasting by changing in their rules. The Fuzzy Rules IF-THEN used in this method, in case of the maximum load is expressed rules based.

IF $X$ is $A_{i}$ AND $Y$ is $B_{i}$ THEN $Z$ is $C_{i}$

The values of input variable $\mathrm{Y}$ are obtained from the neighboring holiday in the year. If the holiday are the days preceding and following holiday, then those values are obtain from the preceding and the following days of the previous holiday. Fuzzy sets $\mathrm{Ai}, \mathrm{Bi}, \mathrm{Ci}$ take the following eleven-term sets:

Negative Very Big (UNVB and LNVB)

Negative Big (UNB and LNB)

Negative Medium (UNM and LNM)

Negative Small (UNS and LNS)

Negative Very Small (UNVS and LNVS)

Zero (UZE and LZE)

Positive Very Small (UPVS and LPVS)

Positive Small (UPS and LPS)

Positive Medium (UPM and LPM)

Positive Big (UPB and LPB)

Positive Very Big (UPVB and LPVB)

\section{Centroid and Karnik-Mendel Algorithms}

Defuzzyfication is a process of mapping the control action fuzzy logic through type-reducer by iterative methods for computing its centroid i.e. Karnik Mendel algorithms to control the action non-fuzzy (crisp). This was possible because the centroid of an Interval Type-2 FSs is an Interval Type-1 FSs, and such sets are completely characterized by their left and right end points; hence, computing the centroid of an Interval Type-2 FS only requires computing those two end points. Defuzzyfication process using the centroid method in the Interval Type-2 FLS has been proposed by Karnik and Mendel [7-9, 12, 13]. Figure 3. shows flow chart of proposed method. Procedures of proposed method as is given in step 1 to 5 as follows:

1. Determination of switch point left $\left(c_{l}\right)$

a. Initialization of $\theta i$ through equation (9)

$\theta_{\mathrm{i}}=\frac{1}{2}\left[\underline{\mu}_{\tilde{\mathrm{A}}}\left(\mathrm{x}_{\mathrm{i}}\right)+\bar{\mu}_{\tilde{A}}\left(\mathrm{x}_{\mathrm{i}}\right)\right]_{i=1,2,3, \ldots N}$

b. Compute $c$ ' through equation (10)

$$
c^{\prime}=c\left(\theta_{1}, \ldots \theta_{N}\right)=\frac{\sum_{i=1}^{N} x_{i} \theta_{i}}{\sum_{i=1}^{N} \theta_{i}}
$$

c. Find $k(1 \leq k \leq N-1)$ such that in equation (11)

$$
\mathrm{x}_{\mathrm{k}} \leq \mathrm{c}^{\prime} \leq \mathrm{x}_{\mathrm{k}+1}
$$

d. Compute $c$ ” for $c_{l}$ through equation (12)

$$
c^{\prime \prime}=\frac{\sum_{\mathrm{i}=1}^{\mathrm{k}} \mathrm{x}_{\mathrm{i}} \bar{\mu}_{\tilde{\mathrm{A}}}\left(\mathrm{x}_{\mathrm{i}}\right)+\sum_{\mathrm{i}=\mathrm{k}+1}^{\mathrm{N}} \mathrm{x}_{\mathrm{i}} \underline{\mu}_{\tilde{\mathrm{A}}}\left(\mathrm{x}_{\mathrm{i}}\right)}{\sum_{\mathrm{i}=1}^{\mathrm{k}} \bar{\mu}_{\tilde{\mathrm{A}}}\left(\mathrm{x}_{\mathrm{i}}\right)+\sum_{\mathrm{i}=\mathrm{k}+1}^{\mathrm{N}} \mu_{\tilde{\mathrm{A}}}\left(\mathrm{x}_{\mathrm{i}}\right)}
$$


e. Check, if $c "=c$ ' then stop, $c l=c$ " If not, set $c^{\prime}=c$ " then return to step 2 .

2. Determination of switch point right $\left(c_{r}\right)$

a. Initialization of $\theta i$ through equation (13)

$$
\theta_{\mathrm{i}}=\frac{1}{2}\left[\underline{\mu}_{\widetilde{\mathrm{A}}}\left(\mathrm{x}_{\mathrm{i}}\right)+\bar{\mu}_{\widetilde{A}}\left(\mathrm{x}_{\mathrm{i}}\right)\right]_{i=1,2,3, \ldots N}
$$

b. Compute $c$ ' through equation (14)

$$
c^{\prime}=c\left(\theta_{1}, \ldots \theta_{\mathrm{N}}\right)=\frac{\sum_{\mathrm{i}=1}^{\mathrm{N}} \mathrm{x}_{\mathrm{i}} \theta_{\mathrm{i}}}{\sum_{\mathrm{i}=1}^{\mathrm{N}} \theta_{\mathrm{i}}}
$$

c. Find $k(1 \leq k \leq N-1)$ such that in equation (15)

$$
\mathrm{x}_{\mathrm{k}} \leq \mathrm{c}^{\prime} \leq \mathrm{x}_{\mathrm{k}+1}
$$

d. Compute $c$ " for $c_{r}$ through equation (16)

$$
c^{\prime \prime}=\frac{\sum_{\mathrm{i}=1}^{\mathrm{k}} \mathrm{x}_{\mathrm{i}} \bar{\mu}_{\tilde{\mathrm{A}}}\left(\mathrm{x}_{\mathrm{i}}\right)+\sum_{\mathrm{i}=\mathrm{k}+1}^{\mathrm{N}} \mathrm{x}_{\mathrm{i}} \underline{\mu}_{\tilde{\mathrm{A}}}\left(\mathrm{x}_{\mathrm{i}}\right)}{\sum_{\mathrm{i}=1}^{\mathrm{k}} \bar{\mu}_{\tilde{\mathrm{A}}}\left(\mathrm{x}_{\mathrm{i}}\right)+\sum_{\mathrm{i}=\mathrm{k}+1}^{\mathrm{N}} \underline{\mu}_{\tilde{\mathrm{A}}}\left(\mathrm{x}_{\mathrm{i}}\right)}
$$

e. Check, if $c^{\prime \prime}=c$ ' then stop, $c r=c$ " If not, set $c^{\prime}=c$ " then return to step 2 .

The $c_{l}$ and $c_{\mathrm{r}}$ are important in centroid calculation. The centroid can be obtained from equation (12) and equation (16) through equation (17).

Centroid $=\left(c_{l}+c_{r}\right) / 2$

Even though centroid calculation is an iteration process, the number of iteration will not exceeds $N$, where $N$ equals the number of sampled values of the primary variable [8].

\section{METHOD}

\section{A. Data Collection}

Holidays in Bali are classified into five types, they are Public, Islamic, Christian, Hindus and Buddhist holidays. Within these types, there are 20 items of holidays in Bali which consist of 14 items of national holidays and 6 items for special Hindu's holidays. By using the calendar of Bali written by Bambang Gde Rawi, the dates and hours of 20 items of holidays in Bali is setup with the peak load data are collected from the period of year 2002 to 2006 [14]. A complete day to day feast is shown in Table 1. Most of the Hindu's holiday in Bali occured two times a year, i.e. every six months. In this case, the peak load forecasting for these days is only chosen once in the course of one year.

The secondary data is taken from Electrical authority (PT. PLN (Persero) P3B Jawa Timur dan Bali Sub Region Bali) located at Kapal power station, Mengwi, Badung. Peak load data from the $4-h$ to $h$ on the day (holidays) based on the date used for forecasting the peak load of each holiday. Peak load data from $h$ up to 4$h$ on holiday based on the date of the year 2003-2004 is used to forecast in the same holiday in 2005 and the years 2004-2005 data are used to forecast the peak load the same holiday in 2006. Actual peak load on the public holidays in 2005 and 2006 is used as a comparison target forecasting.

The peak load system profiles at the day of Idul Adha, four days before holiday and the day of holidays in Bali during the year 2002 to 2004 and the year 2003 to 2005 respectively, can be seen in Figure 4 and Figure 5. as an example.

\section{B. Bali's Electrical System Electrical}

system in the Province of Bali is part of the electric power system interconnecting Madura Java Bali (JAMALI) [15]. The interconnection system from Java to Bali Island uses $150 \mathrm{kV}$ sea cables. Electricity generation in the Province of Bali, is supplied by the interconnection transmissions using sea cables which is laid on sea bed from Ketapang, Banyuwangi to Gilimanuk, Negara with the capacity of $200 \mathrm{MW}$ as well as from Pesanggaran's power station with capacity of 152 MW, 130 MW from Gilimanuk's Power Station and 80 MW from Pemaron's power station, Singaraja. Thus the total power System of Bali was $562 \mathrm{MW}$. It consists of 13 Grids, connected with $150 \mathrm{kV}$ voltage system. One line diagram of $150 \mathrm{kV}$ Transmission System in the Province of Bali can be seen in Figure 6.

\section{Preprocessing Peak Load Data}

Data preprocessing is started firstly by computing some expression and its explanation indicated in equation (18), equation (19) and equation (20) respectively [11]. In order to quantify the difference between the load behavior of special days in this case the holidays and that of normal weekdays, Load Differences (LDs) for maximum loads on holydays are define as the difference between the holiday and the previous four weekdays is expressed by equation (18),

$\operatorname{Max} W D(i)=\frac{W D(i)_{H-4}+W D(i)_{H-3}+W D(i)_{H-2}+W D(i)_{H-1}}{4}$

$L D_{\text {Max }}(i)$ is the maximum load on holidays $(i)$ while $\operatorname{MaxWD}(i)$ is the average maximum load four days before holidays which is given on equation (19),

$$
L D_{\text {MAX }}(i)=\frac{\operatorname{MaxSD}(i)-\operatorname{Max} W D(i)}{\operatorname{Max} W D(i)} \times 100
$$

Based on historical load data, the same holidays with the same day-type showed a tendency to have similar value of $L D$. The Typical LDs (TLDs) is calculated by averaging the $L D s$ of the same holidays in the same daytype collected from the historical data. TLDs is used as a basis to predict the value of the maximum load on holidays.

The Variations of $L D(V L D)$ is defined as the amount of difference between the load behavior of the holiday and typical behaviors of the same holidays with the same day type. Then the values of $V L D_{M A X}$ are calculated simply by subtracting $T L D_{M A X}$ from $L D_{M A X}$ as shown in equation (20).

$$
V L D_{\text {MAX }}(i)=L D_{\text {MAX }}(i)-T L D_{\text {MAX }}(i)
$$

\section{Processing of Interval Type-2 FLS}

In this stages, operation of Interval Type-2 FLS fuzzy set is identical with an operation on Type-1 fuzzy set, however on interval Type-2 fuzzy system; fuzzy operator is done at two type-1 membership function which limit $\mathrm{s}$ the FOU, UMF and LMF to produce firing strength. By using Equation (8), first, all input values of $X, Y$ and output values of $Z$ by definition were changed into its values, where $X$ is $V L D_{M A X}(i)$ for the same holidays on 
previous forecasted years, $Y$ is $V L D_{M A X}(i)$ the previous holiday next to forecasted year and $Z$ is forecast $V L D_{M A X}(i)$. Next, $A_{i}, B_{i}$ and $C_{i}$ were grouped into 22 regions upper and lower of triangle membership function as mention on Sub-section 2.3, then some fuzzy rules bases were made. After that, fuzzy inference system (FIS) with Mamdani method, or used to call Max-Min method was applied. On Mamdani FIS, 5 steps it needs to produce an output: Fuzzyfication, Membership function operation, Implication function, Aggregation, and Defuzzyfication by using KM algorithm through equation (17). This crisp value obtained finally called Forecast $V L D_{M A X}(i)$

\section{E. Post Processing}

In this section forecast load difference is calculated by equation (21) i.e.

$$
\text { Forecast } L D_{M A X}(i)=\text { Forecast } V L D_{M A X}(i)-T L D_{M A X}(i)
$$

To calculate the peak load forecasted in the year $i^{\text {th }}$ (MW) is expressed by Equation (22)

$$
P^{\prime}{ }_{M A X}(i)=\operatorname{MaxWD}(i)+\frac{\left(\text { Forecast } L D_{\text {MAX }}(i) \times \operatorname{MaxWD}(i)\right)}{100}
$$

To find out how far a method to process a particular value when compared with other methods that have been used, or with a value that already exists is successful, one needs to count the difference between values with the calculation method that has real value. This is often called the calculation of the percentage errors in accordance with equation (23).

$\operatorname{Error}(\%)=\left|\frac{P_{M A X}^{\prime}(i)-\operatorname{MaxSD}(i)}{\operatorname{MaxSD}(i)}\right| \times 100$

\section{RESULTS AND DISCUSSION}

In Table 1, the calculation results of forecasting error Interval Type - 2 FLS using data from various types of load conditions in the holidays where this result is just a case of forecasting in year 2006

The implementation of Interval Type - 2 FLS has been presented briefly in Table 2, by comparing from previous results of Type-1 FLS [16], Least square method and Fuzzy Linear Regression [1], respectively. All of the calculation processes are using $\mathrm{m}$ files and running on Matlab's.

\section{CONCLUSION}

Peak load forecasting for holidays using the method of Interval Type-2 Fuzzy Logic System to obtain the average error is very small, as shown in Table 2 . The test results showed a very accurate forecasting with the mean average percentage error (MAPE) of $1.0335 \%$ and $1.5683 \%$ in the year 2005 and 2006 respectively. The highest and the lowest forecasting error in 2005 were $4.172 \%$ and $0.043 \%$ respectively. While, the forecasting error in 2006 obtained the highest average of forecasting of $8.483 \%$ and the lowest error of $0.004 \%$. Error value depends on the value of WDMax and Forecast LDMax respectively. The development of Type-1 to Type-2 intervals FLS in some cases indicates better results.

\section{REFERENCES}

[1] Dharma, Agus., Imam Robandi, Mauridhi Hery P., "Peramalan beban jangka pendek untuk hari-hari libur menggunakan metode fuzzy linear regression (Study Kasus di Pulau Bali)", Proceeding STE UNESA, 2006.

[2] Kyung-Bin Song, Young-Sik Baek, Dug Hun Hong, and G. Jang, "Short-Term load forecasting for the holidays using fuzzy linear regression method", IEEE Transactions on Power Systems, Vol 20, No. 1, 2005.

[3] T.J. Ross, "Fuzzy logic with engineering applications", Singapore: McGraw-Hill, 1995.

[4] B. Kosko, "Fuzzy engineering", New Jersey: Prentice-Hall Inc 1997.

[5] Hiroyuki Mori, "Optimal fuzzy inference for short term load forecasting", IEEE Transactions On Power Systems, Vol. 11, No. 1, pp. 390-396, 1996.

[6] K-H. Kim, "Implementation of hibrid short term load forecasting system using neural network and fuzzy expert systems", IEEE Transactions on Power Systems, Vol. 10, No. 3, pp. 1534-1539, 1995.

[7] Dongrui Wu, Woei Wan Tan, "Computationally efficient typereduction strategies for a type-2 fuzzy logic controller”, The 2005 IEEE International Conference on Fuzzy Systems, pp. 355-359, 2005.

[8] Jerry M. Mendel and Robert I. Bob John, "Type-2 fuzzy sets made simple”, IEEE Transactions on Fuzzy Systems, Vol.10, pp. 117 $127,2002$.

[9] Jerry M. Mendel, Feilong Liu, "Super-exponential convergence of the Karnik-Mendel algorithms for computing the centroid of an interval type-2 fuzzy set", IEEE Transactions on Fuzzy Systems, Vol.15, pp. 309-320, 2007.

[10] J.M. Mendel, "Type-2 fuzzy sets and systems: an overview", IEEE Computational Intelligence Magazine, Vol. 2, pp. 20-29, 2007.

[11] K-H. Kim, "Short Term Load Forecasting for Special Days in Anomalous Load Conditions Using Neural Networks and Fuzzy Inference Method", IEEE Transactions On Power Systems, Vol 15, No. 2, pp. 559-565, 2000.

[12] J.M. Mendel, Hani Hagras, Robert I. John, "Standard background material about interval type-2 fuzzy logic systems that can be used by all authors", 2006 .

[13] Qilian Liang and Jerry M. Mendel, "Interval type-2 fuzzy logic system theory and design", IEEE Transactions on Fuzzy Systems, Vol.8, pp. 535-550, 2000

[14] B.G. Rawi, 2000-2006, Kalender Bali, PT. Mabhakti, Denpasar.

[15] Pemda Badung-Jurusan Teknik Elektro UNUD, 2005, Rencana Umum Kelistrikan Daerah. http://www.ieee-cis.org/ files/standards.t2.win.pdf

[16] Dharma, Agus., Imam Robandi, Mauridhi Hery P., "Aplikasi metode Fuzzy Inference System (FIS) dalam peramalan beban jangka pendek untuk hari-hari libur menggunakan (Study Kasus di Pulau Bali)", Proceeding of The $9^{\text {th }}$ Seminar on Intelligent Technology and Its Applications (SITIA) ITS, pp. 57, Surabaya, 2008 . 


\section{NOMENCLATURE}

LDs = Load Differences

LDMax $(i)=$ Maximum load on holidays

$\operatorname{Max} W D(i)=$ the average maximum load four days before holidays

$\operatorname{MaxSD}(i)=$ The maximum peak load on Special Day

TLDMAX $(i)=$ The Typical Load Difference

$\operatorname{VLDMAX}(i)=$ Variation Load Difference
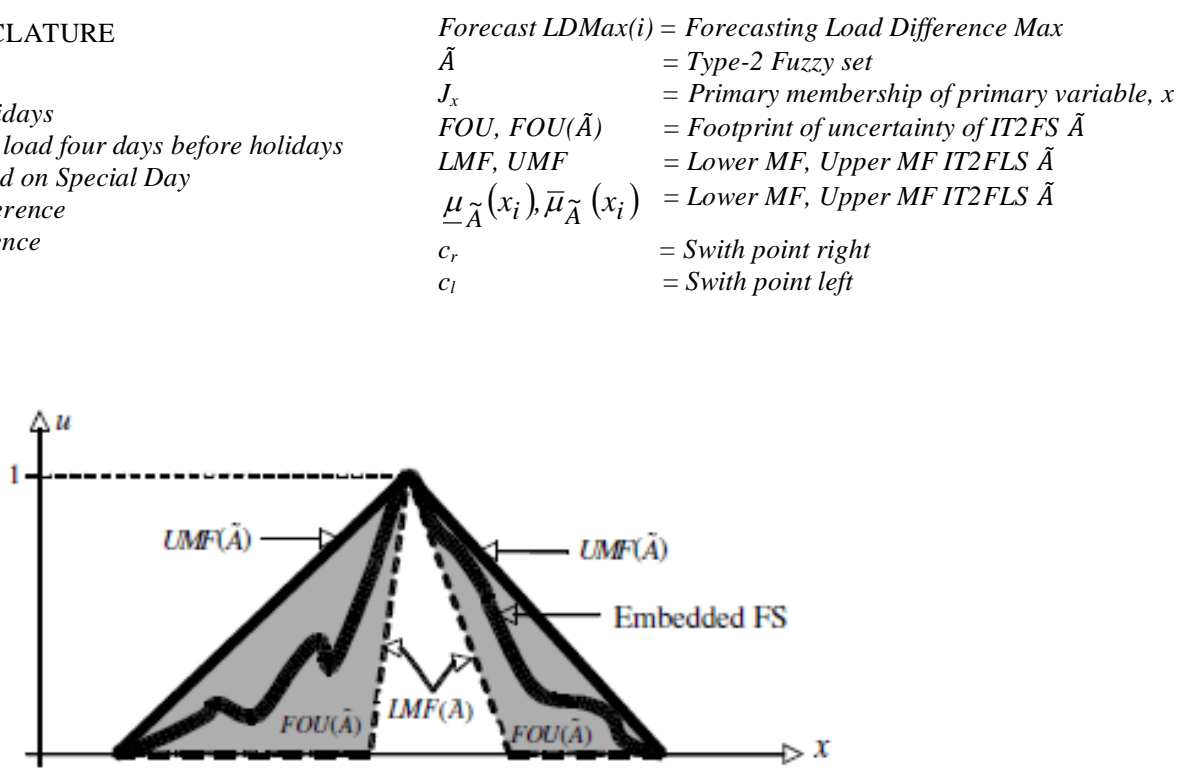

Figure 1. FOU (shaded), LMF (dashed), UMF (solid) and an embedded FS (wavy line) for Interval Type-2 FS $\tilde{A}$

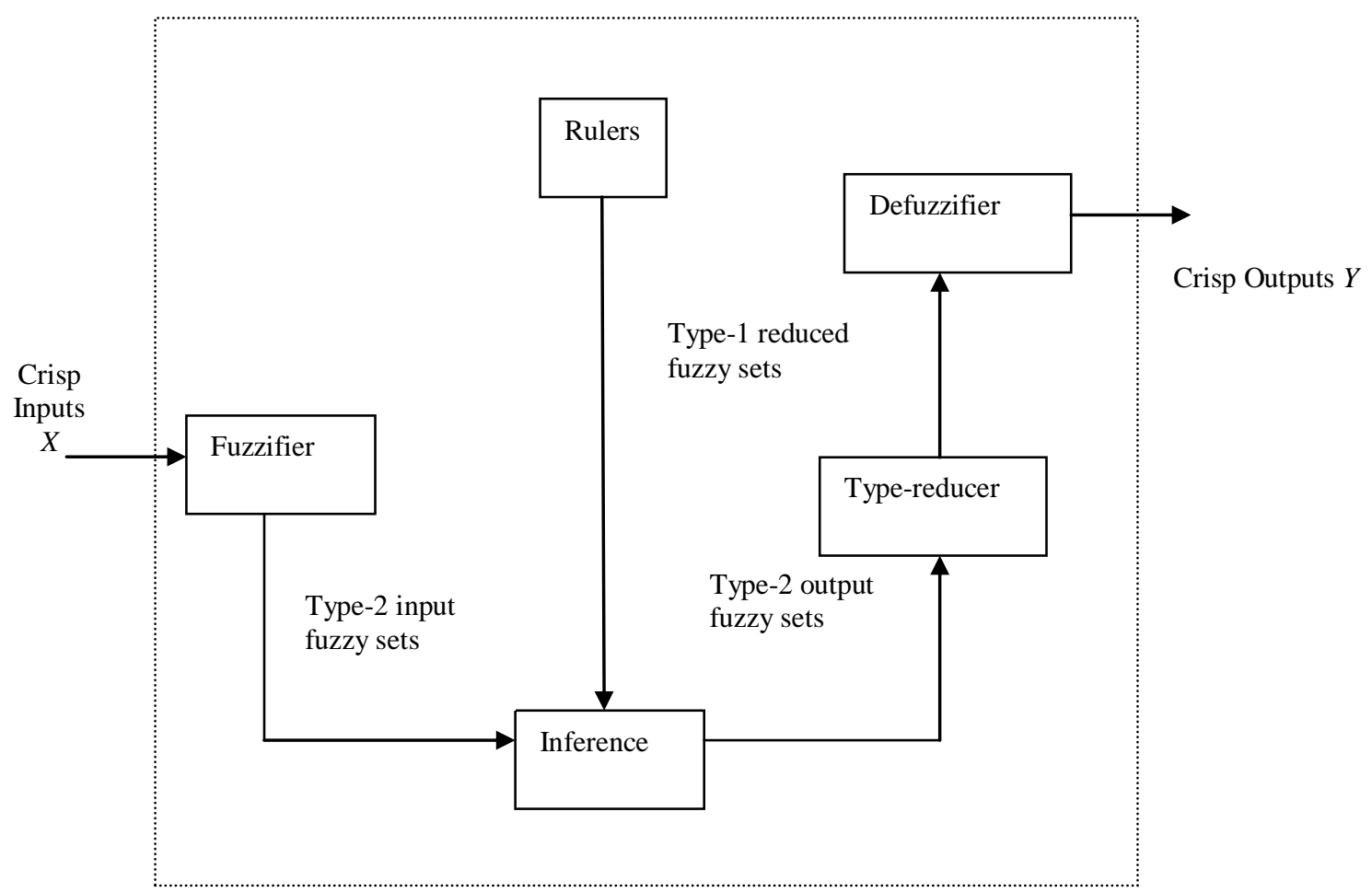

Figure 2. Type-2 Fuzzy Logic System (Type-2 FLS) 


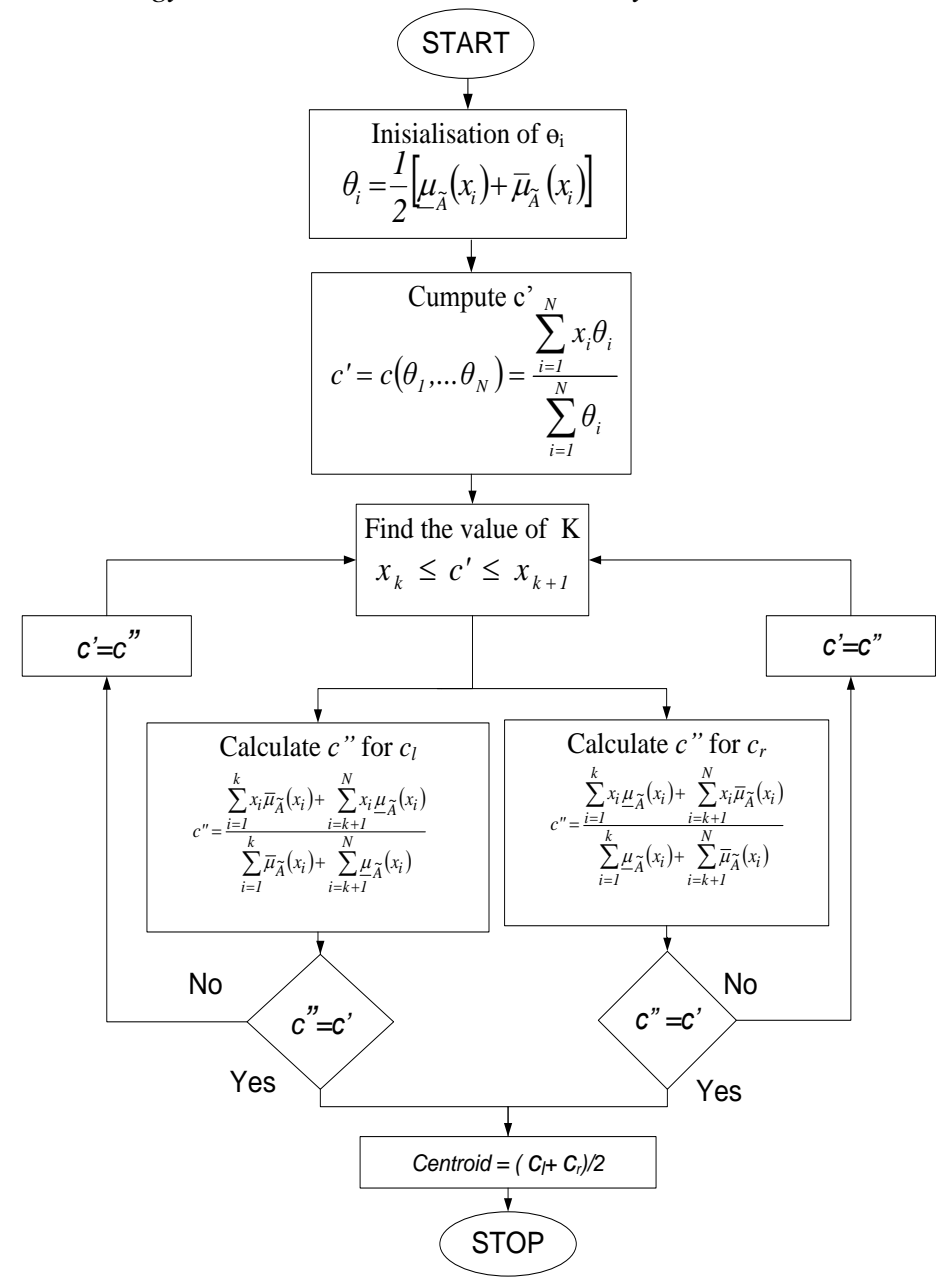

Figure 3. Karnik-Mendel algorithm to calculate centroid on interval type-2 FLS

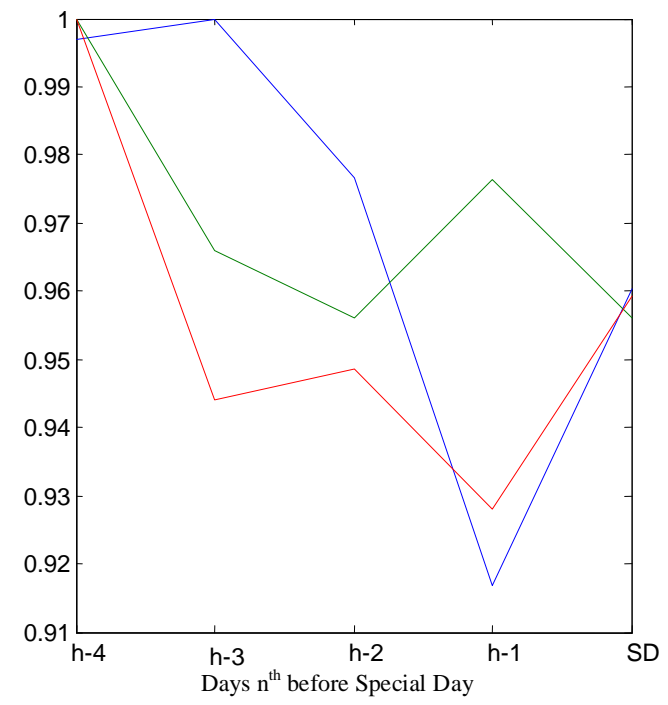

Figure 4. Peak load curves on Idul Adha holydays and its 4 days before in the year 2002 to 2004

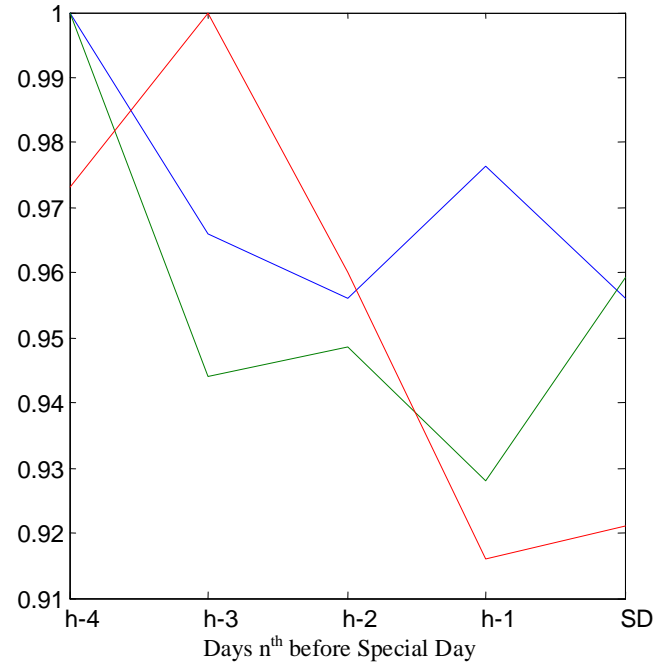

Figure 5. Peak load curves Idul Adha holidays and its 4 days before in year 2003 to 2005 


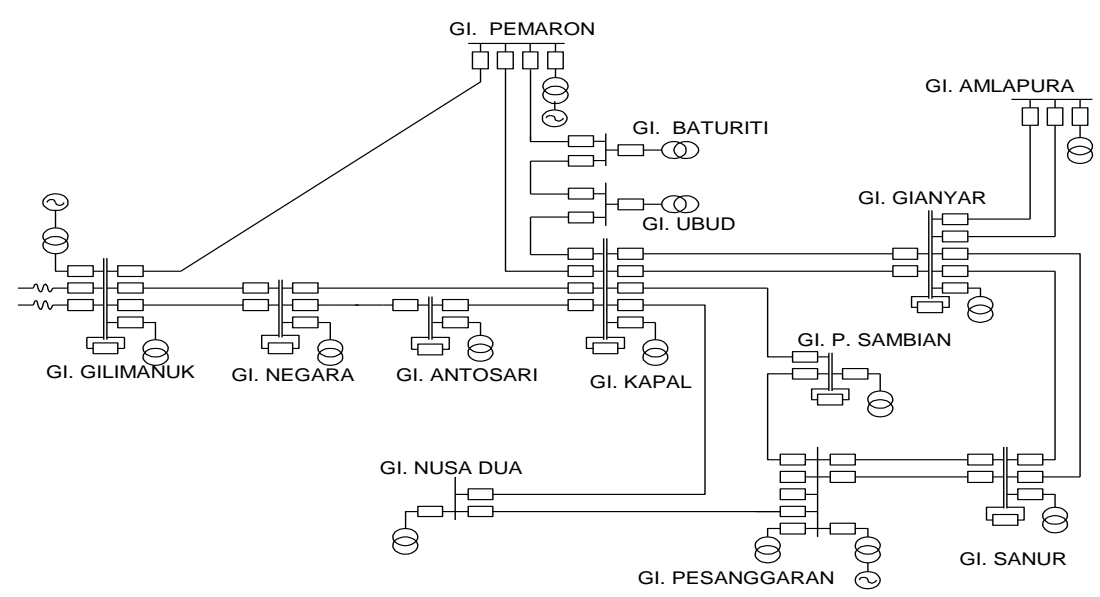

Figure 6. One line diagram of $150 \mathrm{kV}$ transmission system in Bali Island [15]

TABLE 1.

THE RESULT OF FORECASTING ERROR USING INTERVAL TYPE-2 FLS FROM VARIOUS TYPE OF HOLIDAYS IN 2006 IN DETAIL

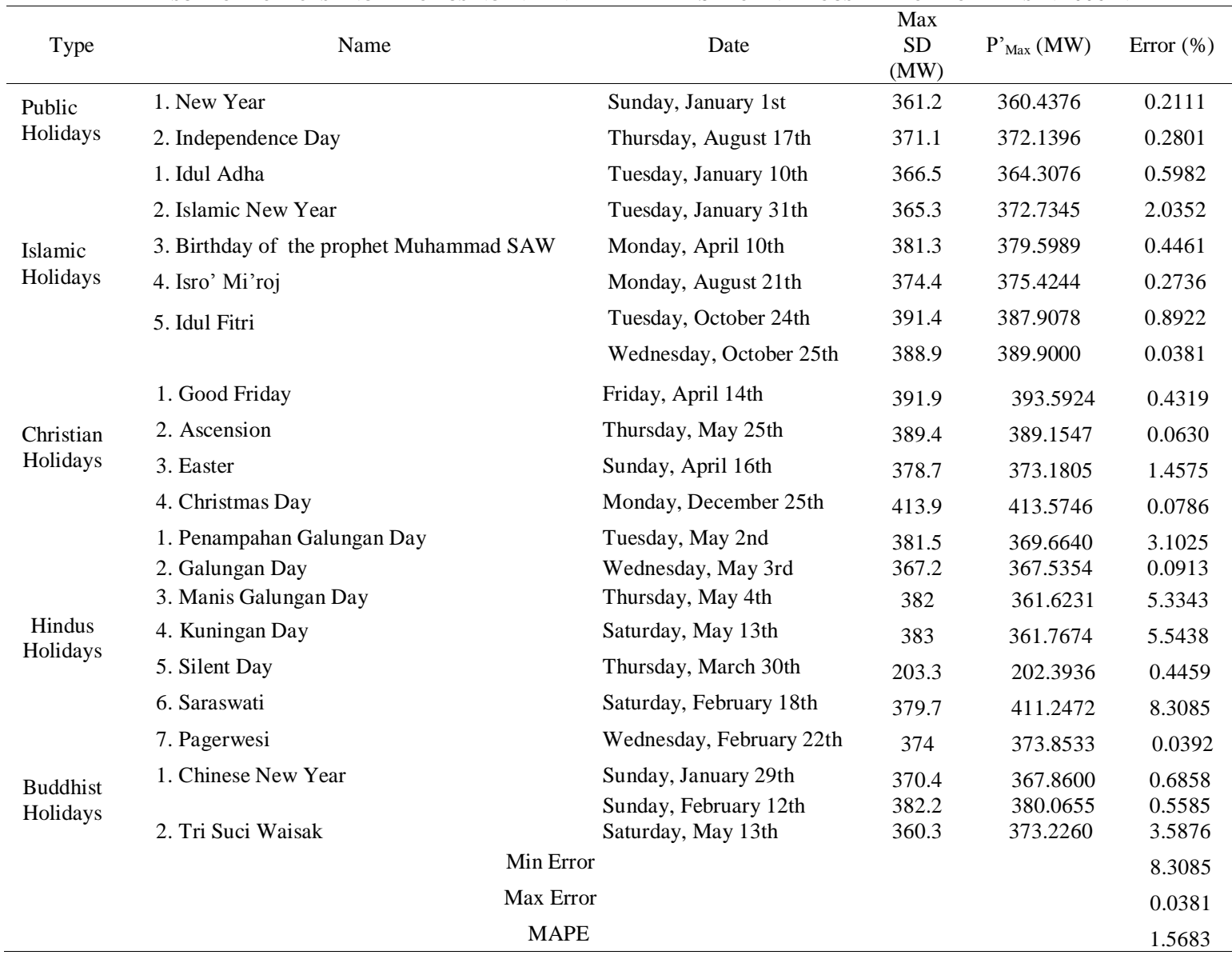

TABLE 2.

THE COMPARISON METHODS OF FORECASTING ERROR

\begin{tabular}{|c|c|c|c|c|c|c|c|c|}
\hline \multirow[b]{2}{*}{20 Holydays } & \multicolumn{8}{|c|}{ Error } \\
\hline & \multicolumn{4}{|c|}{$\begin{array}{c}\text { The data's in the year } 2003 \& 2004 \text { is used to } \\
\text { forecast in } 2005(\%)\end{array}$} & \multicolumn{4}{|c|}{$\begin{array}{l}\text { The data's in the year } 2004 \& 2005 \text { is used to forecast } \\
\text { in } 2006(\%)\end{array}$} \\
\hline Methods & $\begin{array}{c}\text { Least } \\
\text { Square } \\
\text { [1] }\end{array}$ & $\begin{array}{c}\text { Fuzzy } \\
\text { Linear } \\
\text { Regressi } \\
\text { on } \\
{[1]}\end{array}$ & $\begin{array}{c}\text { Type-1 } \\
\text { FLS } \\
{[20]}\end{array}$ & $\begin{array}{l}\text { IntervalTyp } \\
\text { e-2 FLS }\end{array}$ & $\begin{array}{c}\text { Least } \\
\text { Square } \\
{[1]}\end{array}$ & $\begin{array}{c}\text { Fuzzy } \\
\text { Linear } \\
\text { Regressi } \\
\text { on } \\
{[1]}\end{array}$ & $\begin{array}{c}\text { Type-1 } \\
\text { FLS } \\
{[20]}\end{array}$ & $\begin{array}{l}\text { IntervalTyp } \\
\text { e-2 FLS }\end{array}$ \\
\hline MAPE & 6.581 & 4.716 & 0.977 & 1.0335 & 9.307 & 4.546 & 1.645 & 1.5683 \\
\hline
\end{tabular}

